Egyptian Journal of Aquatic Biology \& Fisheries

Zoology Department, Faculty of Science,

Ain Shams University, Cairo, Egypt.

ISSN $1110-6131$

Vol. 23(3): 483-491(2019)

www.ejabf.journals.ekb.eg

\title{
Influence of dietary protein level and feed inputs on growth and feeding performance of the Nile tilapia under biofloc conditions
}

\author{
Amany, A. G. ${ }^{1}$; M.A. Elnady ${ }^{2}$; M.A.I. Salem ${ }^{2}$ and N.E. Metwally ${ }^{1}$ \\ 1- Soilless Culture Dept., Central Laboratory for Agriculture Climate, Giza, Egypt. \\ 2- Animal Production Dept., Fac. of Agric., Cairo University, Giza, Egypt. \\ Corresponding Author:dramany92019@gmail.com
}

\section{ARTICLE INFO \\ Article History: \\ Received:Aug. 28, 2019 \\ Accepted:Sept. 15, 2019 \\ Online:Sept. 19,2019}

\section{Keywords:}

Nile tilapia

crude protein

feeding performance

growth performance

restricted feeding

biofloc culture

\begin{abstract}
The current experiment was designed to test the effect of crude protein content $(25,30$ and $35 \%$ C.P.) as well as restricted feeding in biofloc culture on growth performance of Nile tilapia (Oreochromis niloticus) and water quality dynamics. The experiment included five treatments with duplicate tanks per treatment. Three normal feeding treatments and two restricted feeding treatments were adopted in the experiment. Two feed inputs were employed in the experiment: 1) The normal feeding rates which ranged 1.4 to $1.8 \%$ of fish biomass on daily basis according to season for the 25,30 and $35 \%$ crude protein treatments, 2) The restricted feeding rate at $80 \%$ of the normal feeding rates ( 1.12 to $1.44 \%$ of fish biomass daily) according to season for the $30 \%$ and $35 \%$ crude protein treatments. Molasses were dissolved in water at dry feed to molasses ratio of 1:1 on a daily basis in order to develop biofloc and nourish heterotrophic bacteria. Starting with average initial weights of 13.5 to 20.3 grams/fish, Nile tilapia juveniles grew to harvest weight of 310.2 to 342.1 grams/fish. Increasing dietary protein from $30 \%$ to $35 \%$ within the biofloc treatments did not improve final body weight at harvest. Daily weight gains $(0.82 \mathrm{~g} / \mathrm{fish} / \mathrm{day})$ were slightly improved with the $30 \%$ crude protein diet compared to those of the $25 \%$ crude protein diet $(\mathrm{p}<0.05)$. Similar daily weight gains were obtained when fish were reared under the $30 \%$ restricted protein treatment $(0.77 \mathrm{~g} / \mathrm{fish} /$ day $)$ compared to that of the $30 \%$ crude protein treatment. The higher crude protein content in the $35 \%$ crude protein treatment did not improve daily weight gain of Nile tilapia compared to the $30 \%$ crude protein treatment $(\mathrm{p}>0.05)$. It is recommended to feed Nile tilapia at crude protein level of $30 \%$ in order to obtain acceptable growth with economic returns. Nile tilapia reared under the $30 \%$ crude protein treatment had better PER ratio (1.96) and lower feed costs (15.11 L.E. /kilogram fish) at lower feeding rate compared to the $25 \%$ crude protein treatment.
\end{abstract}

\section{INTRODUCTION}

Biofloc technology is mainly employed to reduce water consumption required to raise aquatic animals while maintaining good water quality parameters in rearing tanks (Crab et al., 2012). Freshwater scarcity is a major problem in the Middle East countries including Egypt. Consequently, the use of biofloc technology conserves its use (Ogello et al., 2014). Desert aquaculture depends on pumping expensive water from deep wells, which limit its development. Consequently, the use of biofloc 
technology optimize the use of fresh water making fish culture more profitable in water scarce areas. Biofloc material rich in protein (i.e. $25-30 \%$ crude protein) is simultaneously produced in rearing units, which can spare dietary protein, reducing the cost of fish production.

Correia et al. (2014) stated that feed is the major driving force of intensive production systems ; consequently, it is important to optimize its use to improve profitability, maximize growth and minimize potential water quality deterioration. This can be done through optimizing crude protein level used to feed fish in biofloc system.

Azim and Little (2008) reported that biofloc is considered as a natural food for fish. Moreover, biofloc material produced in rearing tanks could be used to reduce protein requirement in feed (Burfordet al., 2003; Ballester et al., 2010). As a result, biofloc technology produce low cost material rich in protein (Crab et al., 2007, 2009). In addition, low protein diets produced similar growth performance in shrimp parallel to that of high protein diets (Wasieleasky et al., 2006). Correia et al. (2014) indicated that similar PER values were obtained in both low and high protein diets when fed to shrimp.

Dietary protein is the most expensive ingredient in fish feed which is required to sustain normal growth of aquatic animals. The use of rich protein diets above optimum levels, increases operating costs required to raise fish. Optimum protein levels in biofloc systems should be evaluated in terms of growth and feed performance as well as water quality parameters in culture units. Optimum levels of dietary protein not only reduce production costs, but also ameliorate water quality and growing conditions.

The aim of the present study was to evaluate growth performance and dietary efficiency for Nile tilapia cultured in intensive biofloc system using different crude protein levels and restricted feeding at $80 \%$ of normal feeding rates and determine the best biofloc conditions for tilapia growth and feed efficiency.

\section{MATERIALS AND METHODS}

The study was conducted at The Fish Culture Research Lab, Faculty of Agriculture, Cairo University, Egypt, during 2017 - 2018. A static outdoor rearing system consisting of ten rectangular concrete tanks $(2.2 \times 1.2 \times 1.0 \mathrm{~m})$ were filled with underground water and were used as rearing units for Nile tilapia. Each tank had a water volume of $2.0 \mathrm{~m}^{3}$, with a constant water depth of $75 \mathrm{~cm}$. Nile tilapia juveniles (Oreochromis niloticus) 13.5-20.3 grams/fish were randomly distributed among experimental tanks, with duplicate tanks per treatment. Each tank contained 24 juveniles of Nile tilapia. The experiment duration lasted for 388 days.

\section{Experimental design:}

The current experiment was designed to test the effect of crude protein percent $(25,30$ and $35 \%$ C.P.) of the test diets as well as restricted feeding of Nile tilapia in biofloc culture on growth performance of Nile tilapia and water quality dynamics in concrete tanks. A total of 240 fish were randomly distributed into tanks at the rate of 24 juveniles per tank. Treatments were evenly distributed to tanks and arranged in completely randomized design (CRD). The experiment included five treatments with duplicate tanks per treatment. Two commercial floating feed inputs were employed in the experiment: The first is the normal feeding rates for the 25, 30 and $35 \%$ crude protein treatments (three normal feeding treatments) and the second is the restricted feeding rates at $80 \%$ of the normal feeding rates for the $30 \%$ and $35 \%$ crude protein 
treatments (two restricted feeding treatments). The normal feeding rates depended on stage of growth and season (water temperature) and were applied in the $25 \%, 30 \%$ and $35 \%$ crude protein treatments as follows: $1.4 \%$ of fish biomass during fall, 1.65 $\%$ of fish biomass during spring and $1.8 \%$ of fish biomass during summer, respectively. The two restricted feeding treatments were fed at $1.12 \%, 1.25$ and $1.44 \%$ of fish biomass during fall, spring and summer, respectively. Fish were fed once a day, six days a week during the experimental period. Water were $100 \%$ renewed once every month in each tank. Artificial aeration continued 24-hours a day using a blower (model HG 100, China - 1.5 horse power). Molasses were added to tank water along with the dry feed with a ratio of 1:1 by weight. Molasses were dissolved in water and sprinkled over water surface in each tank on a daily basis in order to develop biofloc and nourish heterotrophic bacteria.

\section{Growth and feeding performance}

Fish in each tank were weighed and counted at the beginning of the experiment and at monthly basis during the experiment. The growth and feed performance parameters were calculated as follows:

Daily weight gain $(\mathrm{DWG} \mathrm{g} /$ day) $=$ (final body weight - initial body weight)/experimental period (days).

Monthly weight gain $(\mathrm{MWG} /$ fish $)(\mathrm{g} / \mathrm{fish})=($ final weight - initial weight $)$ during each month.

Specific growth rate $(\mathrm{SGR} \%)=(\mathrm{In} \mathrm{Wt}-\mathrm{In} \mathrm{W0}) \times 100 / \mathrm{t}$.

Where Wt: is final weight at time t, W0 initial weight, and $t$ is the duration of experiment in days.

Feed conversion ratio $(\mathrm{FCR})=$ dry weight of used feed $(\mathrm{g}) /$ fish weight gain $(\mathrm{g})$.

Protein efficiency ratio (PER) $=$ fish weight gain $(\mathrm{g}) /$ amount of protein fed $(\mathrm{g})$.

Feed cost of production $($ EGP/kg fish $)=$ FCR $\times$ price per kilogram diet.

Water quality parameters

Water temperature and dissolved oxygen were measured using HANNA Instrument dissolved oxygen meter. The $\mathrm{pH}$ was measured on site by $\mathrm{pH}$ digital meter at early morning (7:00 a.m.) and sunset time (30 minutes before sunset), while $\mathrm{pH}$ gain was determined from the difference between early morning and sunset values. Biofloc volume $(\mathrm{ml} / \mathrm{L}$ ) in each tank was measured using the Imhoff cone (one-liter capacity). Visibility was determined using Secchi disk. Nitrite-nitrogen was measured using the diazotizing method and total ammonia concentration (TAN) was measured using the indophenol method employing colorimetric method according to APHA (1995).

\section{Statistical analysis}

Growth performance of the cultured fish as well as water quality parameters in culture tanks were subjected to one-way analysis of variance to determine statistical significant differences among treatments. Differences between means were assessed by Duncan multiple range test (Duncan's, 1955). Statistically significant differences were determined by setting the aggregate type I error at $5 \%(\mathrm{p}<0.05)$ for each comparison. This statistical analysis was performed using the software package SPSS for windows, release 8.0 (SPSS, 1997).

\section{RESULTS AND DISCUSSION}

\section{Average final weight}

Growth performance data of Nile tilapia are shown in Table (1). Starting with average initial individual weights of 13.5 to $20.3 \mathrm{~g} / \mathrm{fish}$, fish grew to an average final 
weight of 310.2 to 342.1 grams. At the end of the culture period, body weights of Nile tilapia differed significantly among treatments $(\mathrm{P}<0.05)$. There was no significant difference in final body weight between the $30 \%$ and $35 \%$ crude protein treatments (340.9-342.1 g/fish) which were significantly higher than that of the $25 \%$ crude protein treatment (310.2 $\mathrm{g} /$ fish).

Table 1: Growth performance and harvest data of Nile tilapia reared under different dietary protein levels

\begin{tabular}{lccccc}
\hline \multirow{2}{*}{\multicolumn{1}{c}{ Parameters }} & \multicolumn{5}{c}{ Treatments } \\
\cline { 2 - 5 } & $\mathbf{2 5 \%}$ & $\mathbf{3 0 \%}$ & $\mathbf{3 5 \%}$ & $\mathbf{3 0 \%}$ Rest. & 35\% Rest. \\
\hline Initial weight (g/fish) & $13.5 \mathrm{c}$ & $17.8 \mathrm{ab}$ & $20.3 \mathrm{a}$ & $16.9 \mathrm{~b}$ & $17.9 \mathrm{ab}$ \\
Initial biomass (g/tank) & $443.3 \mathrm{c}$ & $587.4 \mathrm{ab}$ & $669.9 \mathrm{a}$ & $559.9 \mathrm{~b}$ & $590.7 \mathrm{ab}$ \\
Final weight (g/fish) & $310.2 \mathrm{c}$ & $340.9 \mathrm{ab}$ & $342.1 \mathrm{a}$ & $317.9 \mathrm{bc}$ & $317.7 \mathrm{bc}$ \\
Daily weight gain (g/fish/day) & $0.75 \mathrm{~b}$ & $0.82 \mathrm{a}$ & $0.82 \mathrm{a}$ & $0.77 \mathrm{ab}$ & $0.76 \mathrm{ab}$ \\
Monthly weight gain (g/fish/month) & $22.7 \mathrm{~b}$ & $24.8 \mathrm{a}$ & $24.8 \mathrm{a}$ & $23.1 \mathrm{ab}$ & $23.0 \mathrm{ab}$ \\
Stocking rate(number/tank) & 24 & 24 & 24 & 24 & 24 \\
SGR (\%) & $0.8 \mathrm{a}$ & $0.76 \mathrm{ab}$ & $0.72 \mathrm{~b}$ & $0.75 \mathrm{~b}$ & $0.73 \mathrm{~b}$ \\
Fish harvest (kg/tank) & $6.98 \mathrm{a}$ & $7.00 \mathrm{a}$ & $7.02 \mathrm{a}$ & $7.31 \mathrm{a}$ & $6.82 \mathrm{a}$ \\
Fish harvest (kg/m $\mathbf{3})$ & $3.49 \mathrm{a}$ & $3.50 \mathrm{a}$ & $3.51 \mathrm{a}$ & $3.65 \mathrm{a}$ & $3.41 \mathrm{a}$ \\
Survival rate (\%) & $93.7 \mathrm{a}$ & $85.4 \mathrm{a}$ & $85.4 \mathrm{a}$ & $95.8 \mathrm{a}$ & $89.4 \mathrm{a}$ \\
\hline
\end{tabular}

Increasing dietary protein from $30 \%$ to $35 \%$ within the biofloc treatments did not improve final body weight at harvest, in both normal feeding and restricted feeding treatments. Within the $30 \%$ crude protein treatments, decreasing dietary inputs to $80 \%$ in the restricted treatment decreased harvest weight by only $7 \%$ compared to that of the $30 \%$ treatment.

Xia et al. (2015) indicated that reducing dietary protein in fish feed to appropriate level enhanced growth performance and reduced metabolic ammonia. Similarly, the current results suggest that in the presence of biofloc, it is possible to restrict feeding rates, without affecting harvest weight. This indicates that fish can obtain enough nutrition from different sources in the environment including suspended bioflocs.

\section{Daily weight gain}

The $30 \%$ crude protein diet had significantly $(\mathrm{p}<0.05)$ improved daily weight gain to be $0.82 \mathrm{~g} /$ fish/day compared to $0.75 \mathrm{~g} /$ fish/day which was achieved by $25 \%$ crude protein diet.

Consequently, Nile tilapia were able to extract bacterial protein contained in the biofloc material suspended in tank water in the current experiment which enabled tilapia fed the $25 \%$ crude protein diet to grow significantly slightly lower (by approximately $8.6 \%$ ) than those fed with the $30 \%$ and $35 \%$ crude protein diets in terms of daily weight gain $(\mathrm{p}<0.05)$.

Similar daily weight gain patterns were obtained when fish were reared under the $30 \%$ restricted protein treatment $(0.77 \mathrm{~g} /$ fish/day $)$ compared to those of the $25 \%$ and $30 \%$ crude protein treatments $(0.75$ and $0.82 \mathrm{~g} /$ fish/day, respectively). The use of restricted feeding in fish culture can decrease production costs and enhance water quality in rearing units (Filbrunet al., 2013).

Hargreaves (2006)stated that suspended-growth systems can produce abundant quantities of microbial protein (microbial flocs) which can increase the efficiency of feed utilization. Lowering feed inputs in the current study produced approximately similar growth performance in terms of weight gains.

The higher crude protein content in the $35 \%$ crude protein treatment did not improve harvest weight or daily weight gain of Nile tilapia compared to the $30 \%$ 
crude protein treatment $(\mathrm{p}>0.05)$. Consequently, there is no need to employ higher dietary protein in the diets Nile tilapia raised in biofloc systems.

\section{Water quality parameters}

Water temperature

Water quality data are presented in Table (2). Early morning average of annual water temperature (at 7:00 a.m.) ranged $24.2-26.7^{\circ} \mathrm{C}$ among treatments during the experimental period. Overall averages of annual water temperature at dusk time (30 minutes before dusk) were higher than those of early morning by $1.2-1.5^{\circ} \mathrm{C}$ due to the daily heat gain during daylight hours from sunrise to sunset.

Table 2: Water quality parameters of Nile tilapia reared under different dietary protein levels

\begin{tabular}{lccccc}
\hline \multicolumn{1}{c}{ Parameters } & \multicolumn{5}{c}{ Treatments } \\
\cline { 2 - 6 } & $\mathbf{2 5 \%}$ & $\mathbf{3 0 \%}$ & $\mathbf{3 5 \%}$ & $\mathbf{3 0 \%}$ Rest. & $\mathbf{3 5 \%}$ Rest. \\
\hline Oxygen concentration (mg/l) & $4.3 \mathrm{a}$ & $4.2 \mathrm{a}$ & $4.6 \mathrm{a}$ & $4.9 \mathrm{a}$ & $4.7 \mathrm{a}$ \\
Water temperature $\left(\mathbf{(}^{\mathbf{c}}\right)$ & & & & & \\
Temp. a.m. & $25.3 \mathrm{a}$ & $24.6 \mathrm{a}$ & $24.7 \mathrm{a}$ & $24.2 \mathrm{a}$ & $24.3 \mathrm{a}$ \\
Temp. p.m. & $26.7 \mathrm{a}$ & $26.1 \mathrm{a}$ & $25.7 \mathrm{a}$ & $25.4 \mathrm{a}$ & $25.5 \mathrm{a}$ \\
Temp. difference & $1.4 \mathrm{a}$ & $1.5 \mathrm{a}$ & $1.0 \mathrm{a}$ & $1.2 \mathrm{a}$ & $1.2 \mathrm{a}$ \\
pH reading & & & & & \\
pH a.m. (units) & $7.7 \mathrm{a}$ & $7.7 \mathrm{a}$ & $7.6 \mathrm{a}$ & $7.8 \mathrm{a}$ & $7.7 \mathrm{a}$ \\
pH p.m. (units) & $7.6 \mathrm{a}$ & $7.6 \mathrm{a}$ & $7.7 \mathrm{a}$ & $7.8 \mathrm{a}$ & $7.7 \mathrm{a}$ \\
pH difference & $-0.1 \mathrm{a}$ & $-0.1 \mathrm{a}$ & $0.1 \mathrm{a}$ & $0.0 \mathrm{a}$ & $0.0 \mathrm{a}$ \\
Biofloc volume (ml/l) & $20.5 \mathrm{a}$ & $19.1 \mathrm{a}$ & $25.3 \mathrm{a}$ & $17.4 \mathrm{a}$ & $13.5 \mathrm{a}$ \\
Secchi disk (cm) & $7.7 \mathrm{a}$ & $11.2 \mathrm{a}$ & $10.4 \mathrm{a}$ & $10.1 \mathrm{a}$ & $9.5 \mathrm{a}$ \\
Nitrite (NO2-N, mg/l) & $0.4 \mathrm{a}$ & $0.2 \mathrm{a}$ & $0.1 \mathrm{a}$ & $0.2 \mathrm{a}$ & $0.2 \mathrm{a}$ \\
Ammonia (TAN, mg/l) & $0.0 \mathrm{a}$ & $0.0 \mathrm{a}$ & $0.0 \mathrm{a}$ & $0.0 \mathrm{a}$ & $0.0 \mathrm{a}$ \\
\hline
\end{tabular}

\section{Dissolved Oxygen}

The current experiment reflected a pattern where oxygen concentrations at dusk ranged between 4.2-4.9 mg/l, with no significant differences among treatments. Dissolved oxygen concentrations were slightly higher in the restricted feed treatments due to the lower feed input and its effect on reduced community respiration rates. The current rate of feed inputs induced a very low visibility depth (i.e. Secchi readings), but without oxygen depletion problems due to artificial aeration.

\section{Ammonia and nitrite}

Ammonia concentrations in water in the rearing tanks were near zero, indicating that bacterial activities were very efficient in absorbing metabolic ammonia secreted by fish and/or transforming ammonia to nitrite. Hargreaves (2006) stated that biofloc represents only a temporary packaging of nutrients because nutrients are released upon decomposition of dead bacteria. Averages of nitrite concentrations were relatively low, and ranged from 0.1 to $0.4 \mathrm{mgL}$ among treatments, with no significant differences among treatments. Nitrite-nitrogen concentrations were within acceptable limits. The concentrations of TAN and $\mathrm{NO}_{2}-\mathrm{N}$ of water in the biofloc tanks were lower with adding molasses during the culture period. This is in agreement with Hari and Madhusoodana (2003) and Asaduzzaman et al. (2008) who found out that the use of carbon sources in the biofloc rearing units reduced total ammonia and nitrite concentrations in the rearing environment. TAN concentrations remained near zero during the experiment although fish should have excreted more than $3.0 \mathrm{mg}$ TAN/L/day. Similarly, nitrite concentrations ranged from 0.1 to $0.4 \mathrm{mg} / \mathrm{L}$ among treatments indicating that ammonia oxidizing bacteria worked well in all biofloc treatments. Jatobaet al. (2014) indicated that heterotrophic and nitrifying bacteria work simultaneously in water of the biofloc units, where ammonia and nitrite ions are transformed into harmless nitrate during nitrification. 


\section{Biofloc volume and secchi disk visibilities}

All treatments had shallower photic zone depths $(7.7-11.2 \mathrm{~cm})$ than normal photic zone depth $(30 \mathrm{~cm}$, Boyd, 1990) indicating dense suspension of bacteria. Biofloc volumes (BFV) were nearly similar within and among all treatments over time ( $p>0.05$ ). The decrease of daily feed input from $100 \%$ to $80 \%$ did not affect biofloc volume in culture tanks due to the renewal of water at the end of each month during the experimental period. During a preliminary experiment, it was observed that biofloc volume often exceeds $80 \mathrm{~mL} / \mathrm{L}$ without water renewal (Elnady et al., 2015). Consequently, the design of the current experiment included monthly renewal of $100 \%$ of the water in each tank in order to reduce excessive biofloc volumes in culture tanks.

\section{Early morning and dusk pH}

Early morning and dusk $\mathrm{pH}$ values in water as well as its concentration during daytime hours in rearing tanks are presented in Table (2). Average $\mathrm{pH}$ gains $(\mathrm{pH}$ difference between sunset and morning) during daylight hours were near zero, indicating the lack of photosynthesis in all treatments during daytime hours. Differences between $\mathrm{pH}$ values at early morning and dusk time were low and ranged between -0.1 to 0.1 units.

\section{Feed conversion and protein efficiency ratio}

Feeding performance data are shown in Table (3). Among the dietary treatments, Nile tilapia had slightly higher FCR during spring and summer seasons (1.87 - 2.34) compared to the overall FCR values obtained during warm seasons of the whole experiment (1.51-2.23). The deterioration in feed conversion ratios were due to the slow growth rate of older Nile tilapia during spring and summer seasons which was negatively affected by older growth stage. This indicated that Nile tilapia were more efficient in transforming dietary protein into flesh during early stages of growth compared to those of older fish.

Table 3: Feeding performance and feed cost of Nile tilapia reared under different dietary protein levels

\begin{tabular}{lccccc}
\multicolumn{1}{c}{ Parameters } & \multicolumn{5}{c}{ Treatments } \\
\cline { 2 - 6 } \multicolumn{1}{c}{ Overall FCR } & $\mathbf{2 5 \%}$ & $\mathbf{3 0 \%}$ & $\mathbf{3 5 \%}$ & $\mathbf{3 0 \%}$ Rest. & 35\% Rest. \\
\hline FCR & $2.23 \mathrm{a}$ & $1.7 \mathrm{bc}$ & $1.51 \mathrm{c}$ & $1.82 \mathrm{~b}$ & $1.87 \mathrm{~b}$ \\
\hline (spring and summer seasons) & $2.34 \mathrm{a}$ & $2.05 \mathrm{a}$ & $1.94 \mathrm{a}$ & $1.87 \mathrm{a}$ & $2.09 \mathrm{a}$ \\
\hline Overall PER & & & & & \\
\hline Feed cost (L.E./kg fish) & $1.8 \mathrm{a}$ & $1.96 \mathrm{a}$ & $1.90 \mathrm{a}$ & $1.84 \mathrm{a}$ & $1.52 \mathrm{~b}$ \\
\hline
\end{tabular}

Among the dietary treatments, Nile tilapia had higher FCR with the $25 \%$ crude protein treatment (2.23) compared to all FCR values obtained by other treatments (1.51-1.87). The deterioration in feed conversion ratios in the $25 \%$ crude protein treatment was due to the slightly slow growth rate of Nile tilapia which was negatively affected by lower protein content. The $30 \%$ and $35 \%$ crude protein treatments produced slightly better feed conversion (1.51-1.7) compared to all restricted treatments.

The protein efficiency ratios (PER) were better in all treatments (1.8-1.96) compared to those of the $35 \%$ restricted treatment (1.52). PER values were better in the $25 \%$ and $30 \%$ crude protein treatments than those obtained in the restricted $35 \%$ crude protein treatment. The deterioration in PER ratio in the restricted $(35 \%)$ crude protein treatment may be due to the lower efficiency of protein transformation when high protein diet was used. 
Yang et al. (2002) reported that PERs and Net Protein Utilization (NPU) values were deteriorated when high dietary protein was used in fish diets. Since carbohydrate did not effectively spare protein (Kim et al., 1991).

PERs were significantly deteriorated in the restricted (35\%) protein treatment. Yang et al. (2002) reported that dietary protein can positively enhance fish growth rate to a certain limit, beyond which reduced growth was observed.

Hargreaves and Tucker (2003) indicated that overfeeding can impair growth and feeding performances in cultured fish due to the metabolic waste products resulting from overfeeding. Moreover, when restricted feeding was employed both feeding performance and water quality were ameliorated (Cho and Lovell, 2002). Amirkolaie (2011) pointed out that carbohydrates and fat can spare protein in fish feed, and suitable protein content in fish feed can ameliorate its use by cultured fish.

Similar fish yields per tank were obtained in all treatments $(6.82-7.31 \mathrm{~kg} \backslash \operatorname{tank})$ during the current experiment $(\mathrm{p}>0.05)$. However, the restricted treatment (30\% crude protein) had more economical yield $(7.31 \mathrm{~kg} /$ tank). Heterotrophic bacteria absorb toxic ammonia excreted in the biofloc medium as well as provide biofloc material rich in protein for aquatic animals such as tilapia and shrimp, leading to better growth and feeding performances of cultured organisms (Burfordet al., 2002 and Azim and Little, 2008).

Nile tilapia reared under the $30 \%$ normal feeding treatment had better PER ratio (1.96) and lower feed costs (15.11 L.E. $/ \mathrm{kg}$ fish) compared to the $25 \%$ crude protein treatment.

Ballester et al. (2010) indicated that protein content of feed could be lowered by $10 \%$ when shrimp are reared in biofloc medium without compromising growth rate of cultured animals.

\section{Feed costs}

The results of the current study demonstrated that the biofloc system is more economical in desert aquaculture in terms of water consumption needed to produce fish under limited water availability and high pumping costs.

When Juveniles of Nile tilapia were reared in the biofloc tanks, the amount of daily feed inputs can be reduced without affecting the production costs, indicating that biofloc could contribute to the nutrition and physiological health of Nile tilapia.

Feed costs for producing one kilogram of Nile tilapia were better for the $30 \%$ treatment (15.11 L.E./kg), which was similar to the restricted $30 \%$ and normal feeding $35 \%$ crude protein treatments $(15.86$ - 16.2 L.E. $/ \mathrm{kg})$. Feed costs required to produce one kilogram of fish were higher in the restricted $35 \%$ crude protein treatment and the $25 \%$ treatment. The high feed cost primarily resulted from the high cost of higher protein content as well as the inferior PER ratio obtained when protein input was reduced.

As far as profitability of tilapia production in biofloc tanks is one of the major concerns of the fish farmers, the $30 \%$ crude protein treatment had the most profitable regime to be used in tilapia production during warm season when water temperature are optimal for growth in biofloc systems.

\section{CONCLUSION}

The observed results in the current study indicated that it is possible to use restricted feeding when fish are raised in biofloc tanks. The water quality parameters during the current study were within optimal ranges for Nile tilapia growth. Consequently, it is recommended to use lower protein diets at $30 \%$ crude protein in 
order to obtain higher profitability under biofloc systems. The $30 \%$ crude protein diet is supposed to be used for Nile tilapia production under biofloc environment during warm seasons.

\section{REFERENCES}

APHA (1995).Standard methods for the examination of water and waste water.(19 edition). American Public Health Association, Washington, D. C.

Amirkolaie, A.K. (2011). Reduction in the environmental impact of waste discharged by fish farms through feed and feeding. Reviews in Aquaculture, 3(1):19-26.

Asaduzzaman, M.; Wahab, M.A.; Verdegem, M.C.J.; Huque, S.; Salam, M.A. and Azim, M.A. (2008). C/N ratio control and substrate addition for periphyton development jointly enhance freshwater prawn Macrobrachium rosenbergii production in ponds. Aquaculture, 280(1-4), pp.117-123.

Azim, M.E.; Little, D.C. and Bron, J.E. (2008). Microbial protein production in activated suspension tanks manipulating $\mathrm{C}: \mathrm{N}$ ratio in feed and the implication for fish culture. Bio resource Technology, 99(9): 3590-3599.

Ballester, E.L.C.; Abreu, P.C.; Cavalli, R.O.; Emerenciano, M.; Abreu L. and Wasielesky, W. (2010). Effect of practical diets with different protein levels on the performance of Farafantepenaeus paleness juveniles nursed in a zero exchange suspended microbial floc intensive system. Aquaculture Nutr., 16: 163-172.

Boyd, C.E. (1990). Water Quality in pond for Aquaculture.Alabama Agricultural Experimental Station, Aubun University, Auburn, AL, 482 p.

Burford, M.A.; Pearson, N.P.; Glibert, P.M. and Dennison, W.C. (2002).Tracing the fate of 15N-enriched feed in an intensive shrimp system. Aquaculture, 206:199-216.

Burford, M.A.; Thompson, P.J.; McIntosh, R.P.; Bauman, R.H. and Pearson, D.C. (2003).Nutrient and microbial dynamics in high-intensity, zero-exchange shrimp ponds in Belize. Aquaculture, 219: 393-411.

Cho, S.H. and Lovell, R.T. (2002). Variable feed allowance with constant protein input for channel catfish (Ictalurus punctatus) cultured in ponds. Aquaculture, 204(1):101-112.

Crab, R.; Avnimelech, Y.; Defoirdt, T.; Bossier, P. and Verstraete, W. (2007).Nitrogen removal in aquaculture towards sustainable production. Aquaculture, 270:1-14.

Crab, R.; Kochva, M.; Verstraete, W. and Avnimelech, Y. (2009).Bio-flocs technology application in over-wintering of tilapia. Aquaculture Engineering, 40: 105-112.

Crab, R.; Defoirdt, T.; Bossier, P. and Verstraete, W. (2012). Biofloc technology in aquaculture: beneficial effects and future challenges. Aquaculture, 356:351-356.

Elnady, M.A.; Abd El wahed, R.K. and Younes, A.F. (2015).Effect of restricted feeding and partial water renewal on water quality and growth performance of Nile tilapia under biofloc culture. The Bulletin. Fac. Agric., Cairo Univ., 66: 223-233.

Filbrun, J. E.; Reynolds, C. A. and Culver, D. A. (2013).Effects of feeding rate on habitat quality in fish rearing ponds. Journal World Aquaculture Society, 44 (2):198-209.

Hargreaves, J.A. and Tucker, C.S. (2003).Defining loading limits of static pond for catfish aquaculture. Aquaculture Engineering, 28:47-63.

Hargreaves, J. A. (2006). Photosynthetic suspended-growth systems in aquaculture. Aquaculture Engineering, 34:344-363.

Hari, B. and MadhusoodanaKurup, B. (2003).Comparative evaluation of dietary protein levels and plant- animal protein ratios in Macrobrachium rosenbergii (de Man). Aquaculture Nutrition, 9(2): 131-137.

Jatoba A.; da silva, B.C.; da silva, J.S.; do Nascimento Vieira, F.; Mourino, J.L.P.; Seiffert, W.Q. and Toledo, T.M. (2014). Protein levels for Litopenaeus vannamei in semi-intensive and biofloc systems. Aquaculture, 432: 365-371. 
Kim, K.; Kayes, T.B. and Amundson, C.H. (1991).Purified diet development and reevalution of the dietary protein requirement of fingerling rainbow trout (Oncorhyncus mykiss). Aquaculture, 96:57-67.

Ogello, E. O.; Musa, S. F.; Aura, C. M.; Abwao, J. O. and Munguti, J. M. (2014). An Appraisal of the Feasibility in Ponds Using Biofloc Technology: A review. International journal of aquatic science, 5(1): 21-39

Wasielesky, Jr.W.; Atwood, H.; Stokes, A. and Browdy, C.L. (2006). Effect of natural production in a zero exchange suspended microbial floc based super-intensive culture system for white shrimp Litopenaeus vannamei. Aquaculture, 258: 396403.

Xia, S., Sun, Z.; Feng, S.; Zhang, Z.; Rahman, M.M. and Rajkumar, M. (2015). Effects of dietary protein level on growth and ammonia excretion of leopard coral grouper, Plectropomus leopardus (Laceped,1802). Sains Malaysiana, 44(4): pp.537-543.

Yang, S.; Liou, C. and Liu, F. (2002). Effects of dietary protein level on growth performance, carcass composition and ammonia excretion in juvenile silver perch (Bidyanus bidyanus). Aquaculture, 213:363-372.

\section{ARABIC SUMMARY}

\section{تأثير مستوى بروتين العليقة و معدل التغذية على أداء النمو و التغذية للبلطى النيلى تحت ظروف البيوفلوك

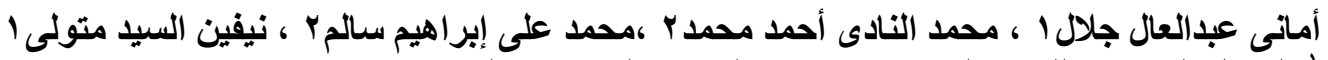

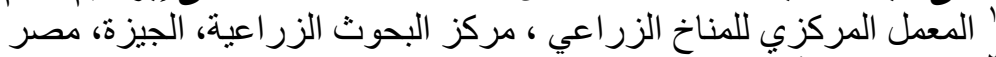

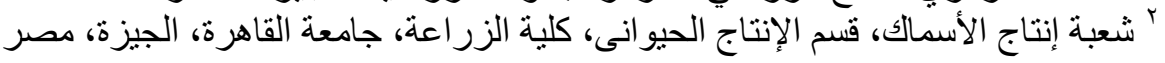

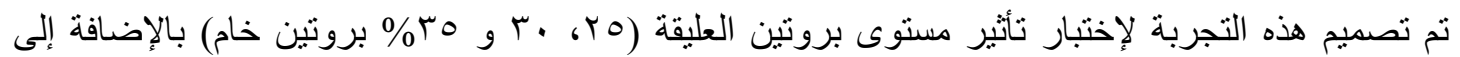

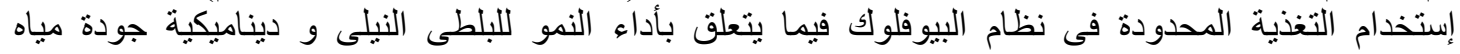

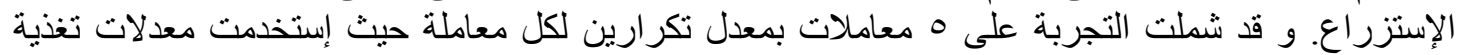
كالتالى:

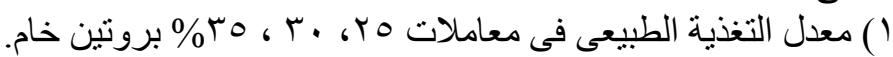

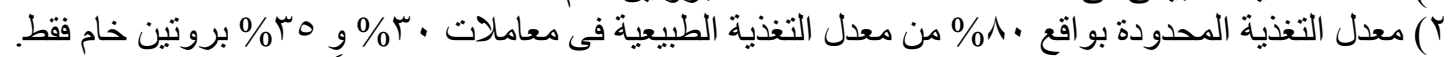

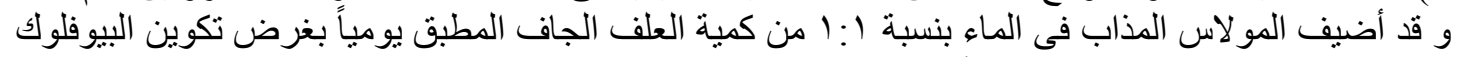

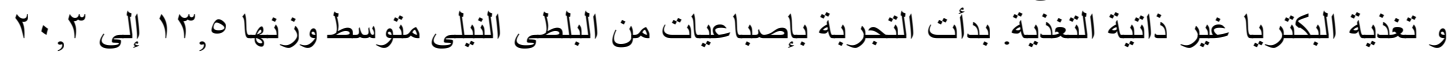

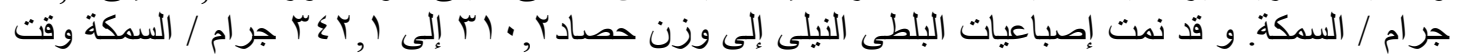

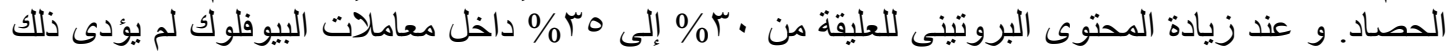

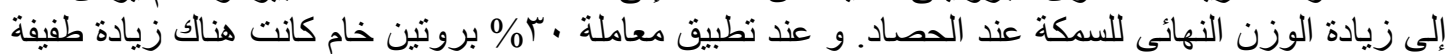

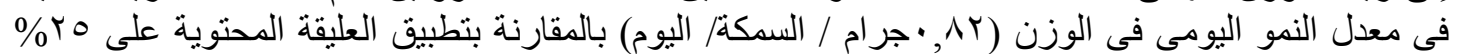



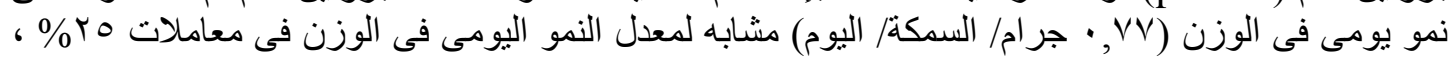

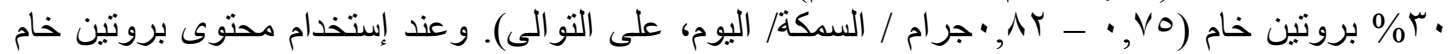

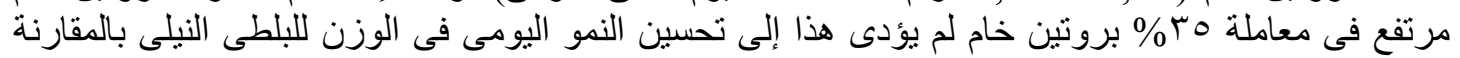

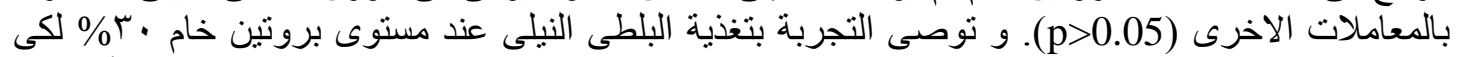

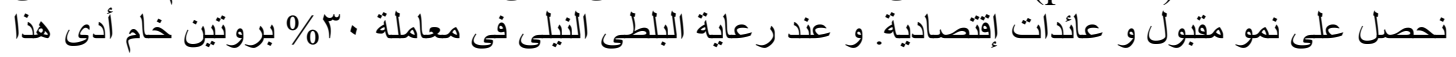

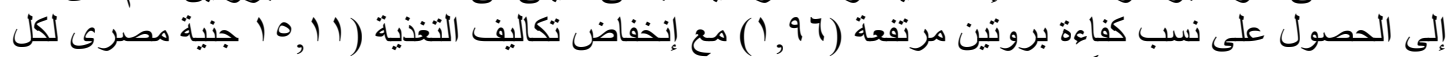

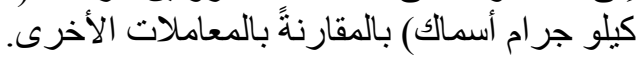

